\title{
The First World War and its influence on the development of orthopaedic surgery
}

\author{
T Scotland \\ Retired Orthopaedic Surgeon, NHS Grampian; Honorary Senior Lecturer University of Aberdeen, Aberdeen, UK
}

\begin{abstract}
By December 19/4, overwhelming numbers of soldiers with infected musculoskeletal wounds had filled hospitals in France and Britain. Frequently initial management had been inadequate. In 1915, patients with orthopaedic wounds were segregated for the first time when Robert Jones established an experimental orthopaedic unit in Alder Hey Hospital, Liverpool. In 1916 he opened the first of 17 orthopaedic centres in Britain to surgically treat and rehabilitate patients. Henry Gray from Aberdeen emerged as the leading authority in the management of acute musculoskeletal wounds in casualty clearing stations in France and Flanders. Gray had particular expertise in dealing with compound fractures of the femur for which he documented an $80 \%$ mortality rate in 1914-15.
\end{abstract}

\author{
Correspondence to T Scotland \\ I 7 Marchbank Road \\ Bieldside \\ Aberdeen ABI5 9DJ, UK
}

tel $+44(0) / 224867237$

e-mail thomasscotland@btinternet.

com

KEYWORDS compound fracture of femur, First World War, Henry Gray, Robert

Jones, orthopaedic surgery

DECLARATIONS OF INTERESTS No conflicts of interest declared.

Following the outbreak of the First World War in August 1914, medical services in France and Flanders were confronted by huge numbers of soldiers with grossly contaminated musculoskeletal wounds. These men were evacuated by a designated pathway to base hospitals, where they underwent definitive surgery (Figure I). Many lives were lost as a result of this policy. It took too long to reach base hospitals and organisms responsible for causing gas gangrene had an opportunity to thrive.

\section{EVACUATION PATHWAY AND ITS MODIFICATION}

Each battalion of approximately I,000 officers and men had a regimental medical officer who administered medical care to the sick and wounded. Sixteen regimental stretcher bearers retrieved the wounded from No Man's Land and transported them to the Regimental Aid Post close to the front line, where they were given basic treatment before a field ambulance took over their care.

A field ambulance was a medical facility positioned roughly two miles from the front line. It had a tent division and a stretcher bearer division. Three field ambulances were allocated to an infantry division of approximately 12,000 men. The tent divisions of the ambulances pooled resources to establish an advanced dressing station (ADS) and main dressing station (MDS) to treat the wounded, while the stretcher bearer divisions collected the wounded and transported them from the Regimental Aid Post to these locations. Each ambulance was made up of three identical sections capable of independent action. Surgery was performed infrequently at ADSs during the early years of the war, although by 1918 experienced surgeons performed life-saving surgery in these forward positions.'

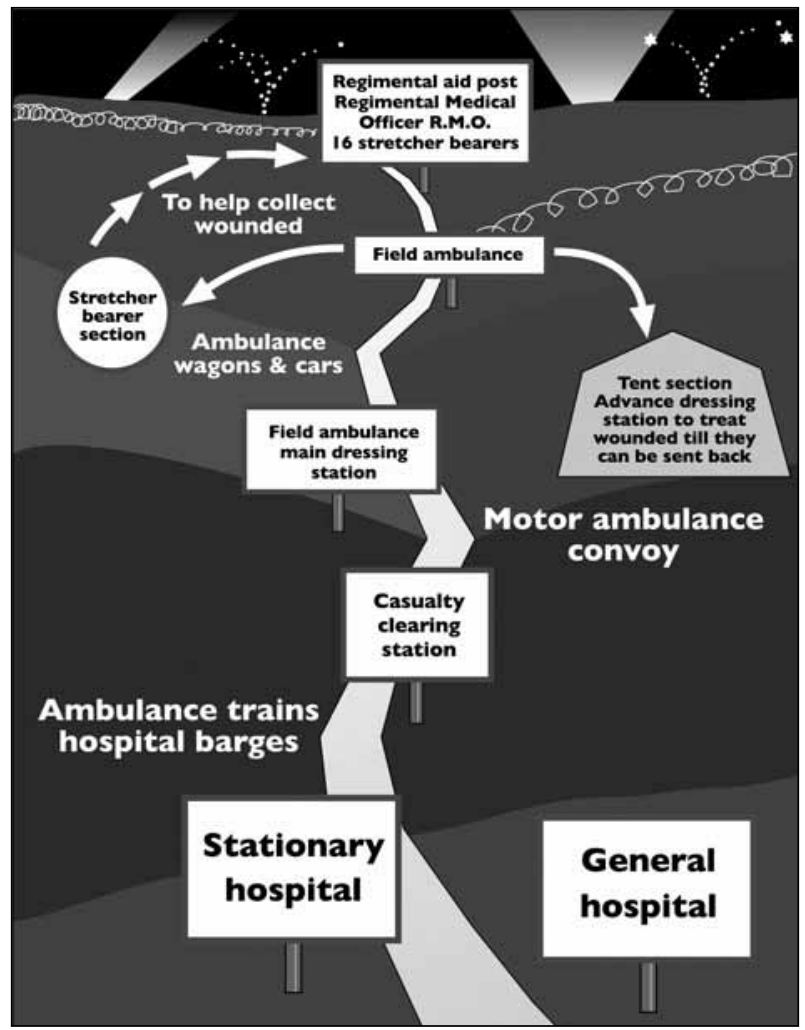

FIGURE I Evacuation pathway for casualties from point of wounding to base hospitals (Gordon Stables, Department of Medical Illustration, University of Aberdeen).

From the ADS, patients were transported to the MDS or to casualty clearing stations (CCSs), depending on the severity of their wounds. Casualty clearing stations were usually out of range of shell fire, at a minimum of 10,000 yards from the front line, and could be reached relatively 
TABLE I Causes of wounds sustained in 24 hours during the Third Battle of Ypres, on 21 September 1917

\begin{tabular}{|l|c|c|}
\hline Wounding agent & No. of wounds & Percentage \\
\hline High explosive & 3,867 & $35.8 \%$ \\
\hline Shrapnel & 2,142 & $19.9 \%$ \\
\hline Bullet & 2,933 & $27.2 \%$ \\
\hline Hand grenade & 77 & $0.70 \%$ \\
\hline Bayonet & 17 & $0.16 \%$ \\
\hline Gas & 209 & $1.94 \%$ \\
\hline Uncertain & 1,544 & $14.3 \%$ \\
\hline Total & 10,789 & $100 \%$ \\
\hline
\end{tabular}

From: MacPherson WG, History of the Great War based on official documents, p. I70-1. ${ }^{3}$

quickly by motor ambulance convoys. They were usually constructed from pre-fabricated wooden huts, in close proximity to a railway. Their purpose was to clear casualties by hospital train to base hospitals for surgery.

Because of the problem of gas gangrene caused by delay in surgical intervention, Sir Anthony Bowlby, Senior Consulting Surgeon to the British Expeditionary Force, stated that patients with filthy wounds had to have definitive treatment as soon as possible after the infliction of the wound, because gas gangrene could become widely spread within 24 hours. It was necessary to operate on such cases before patients were sent by train to the base. ${ }^{2}$

Casualty clearing stations were chosen to perform this surgery. During the Third Battle of Ypres (3I July-10 November 1917), CCSs performed 61,423 operations, or $30 \%$ of definitive surgical procedures. ${ }^{3}$

The personnel at a CCS normally comprised eight officers and 77 other ranks. One of the medical officers had dental qualifications. Nursing sisters were added in 1915 , at first five and then seven. A CCS had two surgical teams during quiet spells, consisting of a surgeon, anaesthetist, theatre sister and an operating theatre orderly. When reinforcements were required during a battle, surgical teams were sent from tent sections of field ambulances, from other CCSs in quiet locations and from base hospitals.

Casualty clearing stations closest to the front treated those patients in greatest need. Soldiers with abdominal wounds, chest wounds and compound fractures of the femur came into this category. Clearing stations could accommodate $800-1,200$ patients and three or four with similar designated expertise were grouped together so that 'on call' could be passed from one to another.

Wounded soldiers were assessed by an experienced surgeon. Those with severe wounds, considered safe to wait a few hours, were put on hospital trains and sent

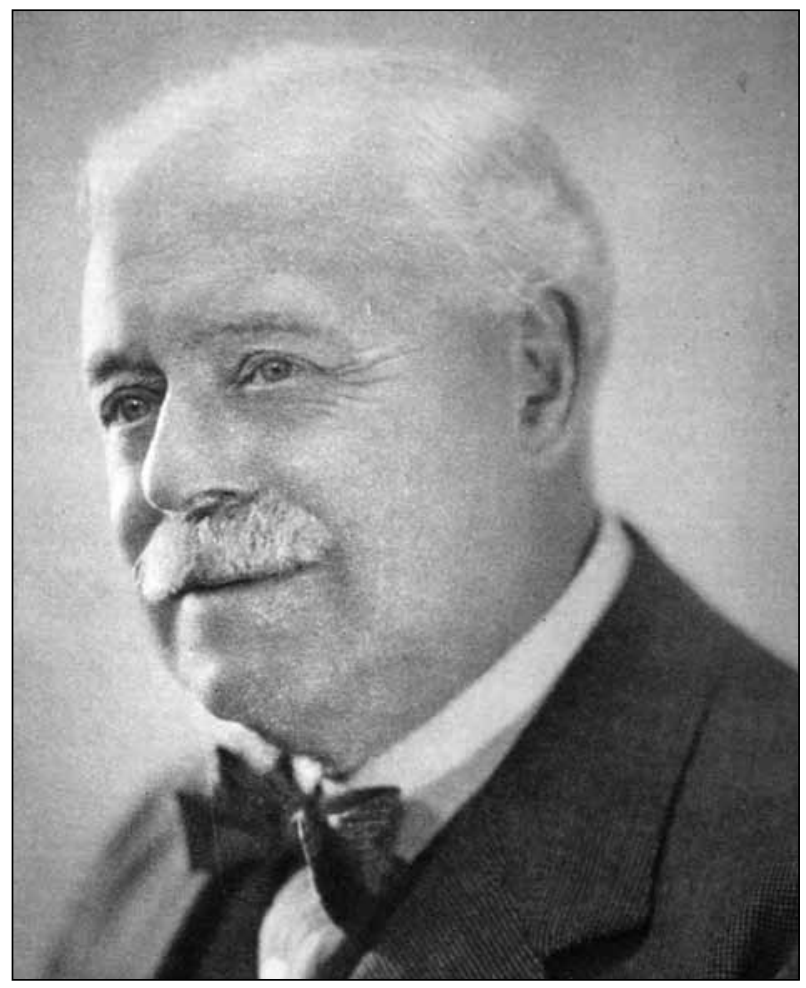

FIGURE 2 Sir Robert Jones (Private collection).

immediately to base hospitals for surgery. Those with minor wounds were admitted for surgery in a minor operating theatre. All devitalised tissue was thoroughly excised. Most of these men could be returned to duty relatively quickly. Men with wounds requiring immediate limb- and life-saving surgery underwent treatment at the earliest opportunity at CCSs in operating theatres equipped to deal with major cases.

Artillery fire caused the greatest number of casualties in the First World War. Fragments of high explosive shell or shrapnel balls were responsible for $58 \%$ of wounds in a series of 212,659 cases. ${ }^{4}$ Rifle and machine gun bullets were responsible for $39 \%$ of wounds, while hand grenades caused $2.19 \%$. Bayonet wounds were conspicuous by their absence and were only responsible for $0.32 \%$ of admissions, either because they did not occur or else were usually fatal and rarely reached medical services. In a 24-hour 'snapshot' during the Third Battle of Ypres, there were 10,789 admissions to CCSs on 21 September 1917 (Table I). ${ }^{3}$

In August 1914, Liverpool surgeon Robert Jones (18571933) joined the reserve as a captain and was attached to the IstWestern General Hospital at Fazakerley, Liverpool. Jones (Figure 2) was quickly promoted to the rank of major and one of his duties was to visit hospitals of Western Command. Like all British surgeons, Jones was a general surgeon, but he had extensive experience in musculoskeletal surgery. The Welsh medical practitioner Hugh Owen Thomas (|834-9|) was his uncle by marriage, and Jones lived with Thomas from the age of 16. 
Thomas was an innovative, eccentric practitioner who wrote extensively but never appended his medical qualification to published work and never held a hospital appointment. Many thought that Thomas, like his forebears, was an unqualified bone-setter. His patients were the poor and the destitute living around the docklands of Liverpool. Many suffered from tuberculosis and joint disease was common. Thomas had a workshop in his premises at II Nelson Street, Liverpool, where he invented many splints, including one to immobilise knee joints affected by tuberculosis.

Jones studied medicine at Liverpool and became a Fellow of the Royal College of Surgeons of Edinburgh. Unlike his uncle, Jones was very outgoing. He was appointed surgeon-superintendent to the Manchester Ship Canal, built between 1887 and 1894. A total of 20,000 workmen were employed in its construction and Jones treated more than 200 major injuries..$^{5}$ This experience would stand him in good stead for the First World War.

After completing his inspection of hospitals in 19/4, Jones wrote a damning report that reached Director General of Army Medical Services, Sir Alfred Keogh. Jones highlighted large numbers of soldiers with musculoskeletal wounds who had been passed from one hospital to another to free up beds and who had been treated badly. These crippled soldiers were neither fit for military duty nor for return to civilian life.

Sir Berkeley Moynihan from Leeds was one of the most influential general surgeons at the time. Before the war he had established the Provincial Surgeons' Club to bring together surgeons who practised in 'the provinces' (which for practical purposes meant outside London!); Jones was a founder member. Moynihan admired Jones, often referring to him as 'Grandpa'. Moynihan visited hospitals in France between December 1914 and March 1915 and declared that the treatment of compound fractures was deplorable. The country would soon be 'flooded by men doomed to deformity and crippling' ${ }^{6}$

As a result of the reports submitted by Jones and Moynihan, Keogh invited Jones to open an experimental orthopaedic unit in Alder Hey, Liverpool, in the spring of 1915, segregating patients with orthopaedic wounds for the first time. In total, 250 beds were allocated; this quickly increased to $560 .^{5}$

The Alder Hey unit was so successful that Jones opened the first orthopaedic centre on the site of the Hammersmith Workshop at Shepherd's Bush in London in March 1916. This centre fulfilled two roles. First, orthopaedic problems such as non-union, mal-union and peripheral nerve injuries, all complicated by sepsis, were dealt with surgically. Second, facilities to rehabilitate soldiers were provided. They were given an occupation

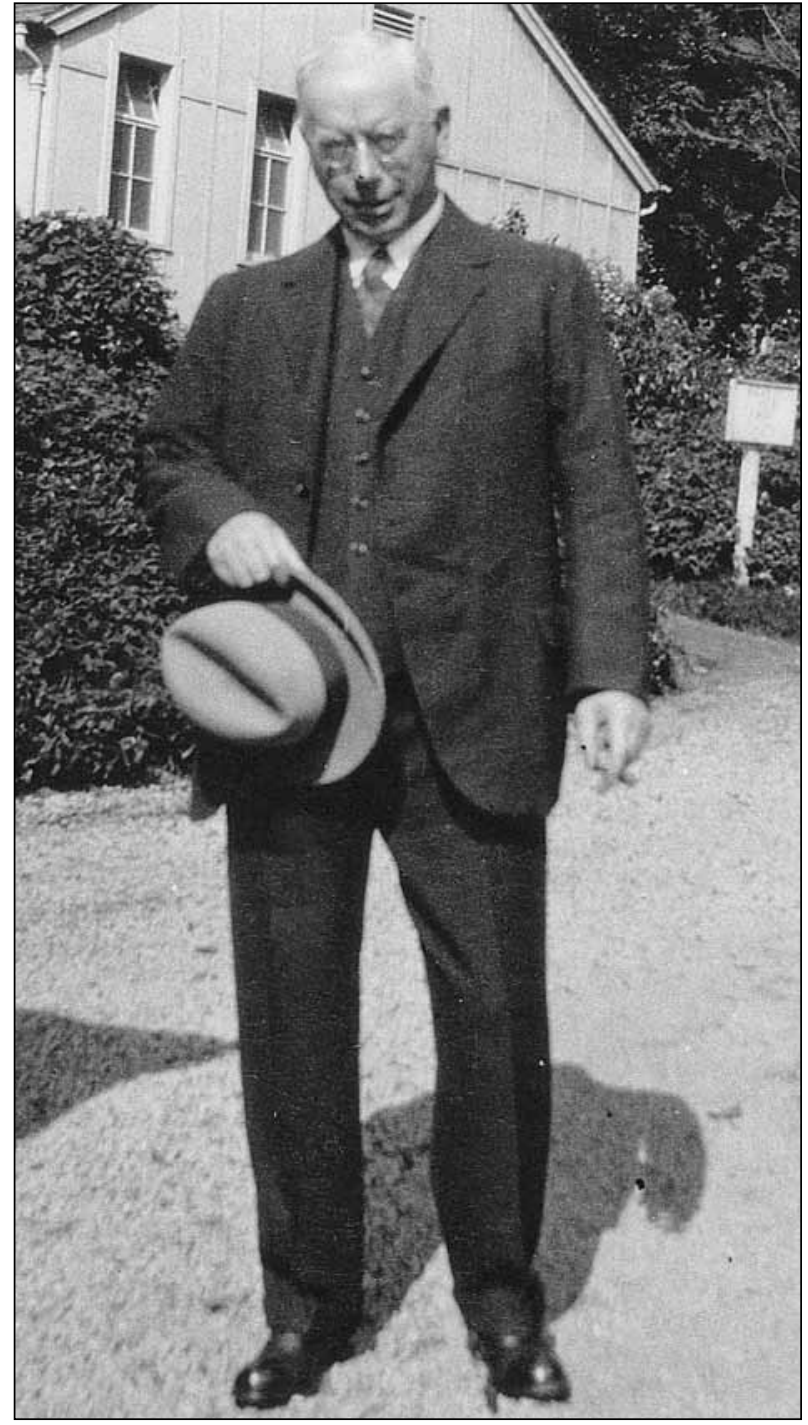

FIGURE 3 Sir Henry Gray (Courtesy of Dr lan Levack).

in a 'curative workshop' which helped to improve function and to restore morale. Soon there were 17 orthopaedic centres around the UK, including three in Scotland: one at Old Mill Hospital in Aberdeen, better known to-day as Glenburn Wing, Woodend Hospital; a second at Bangour Hospital near Edinburgh, which specialised in the management of peripheral nerve wounds; and a third at the site of the Red Cross Hospital in Bellahouston Park in Glasgow. Three quarters of patients admitted to orthopaedic centres returned to some form of military activity. ${ }^{5}$

These developments were frowned upon by Londonbased surgeons, who believed that surgical innovation could only take place in London. The president of the Royal College of Surgeons of England, GH Makins, stated:

We find a specialist for the treatment of fractured jaws; another for fractures of the thigh; and third, strange inconsistency, we meet a third department, that of orthopaedics - for which a special course of a few 


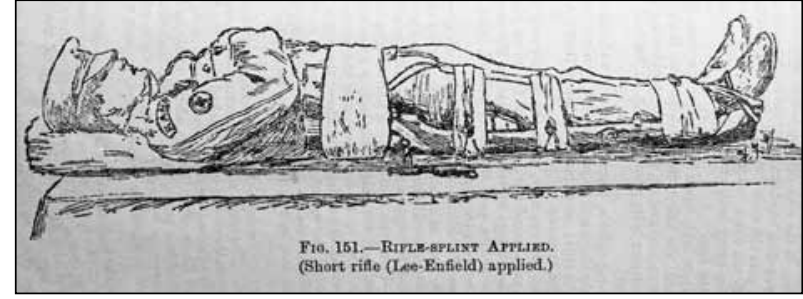

FIGURE 4 Rifle Splint; from Royal Army Medical Corps Handbook, I91 I; a Lee-Enfield Rifle was strapped to the affected limb and to the pelvis. It was not effective in immobilising the fracture.

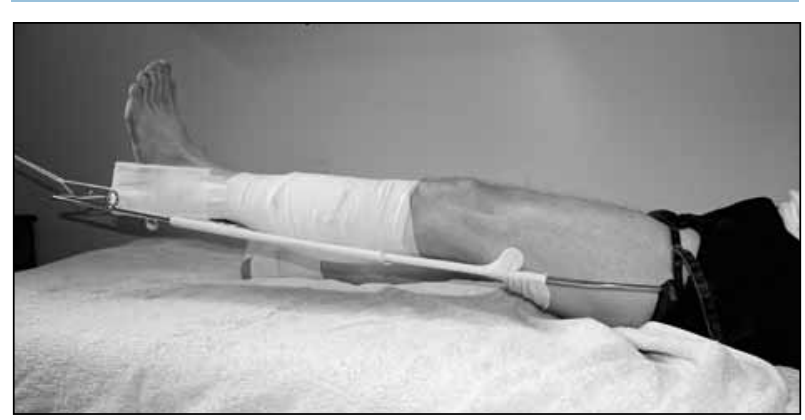

FIGURE 5 Thomas Splint showing how longitudinal traction is applied to the limb to overcome muscle spasm and maintain reduction of the fracture; by effectively immobilising the fracture, the Thomas Splint helped to reduce blood loss (author's photograph).

months in some instances suffices to qualify - claiming almost the whole field of the surgery of injuries. ${ }^{7}$

Jones was made Director of Military Orthopaedics in 1916 by Sir Alfred Keogh as a result of sustained pressure by Moynihan. Keogh knew he would face opposition from London surgeons, stating that they would have his head on a charger! ${ }^{6}$ Moynihan told Keogh that unless Jones was appointed Director of Military Orthopaedics, then he, Moynihan, would resign. ${ }^{6}$ Not only was Moynihan influential in Jones' appointment, he was also powerful enough to keep him in post, fending off unwelcome attention from the surgical establishment.

Jones dealt mainly with the late sequelae of frequently mismanaged orthopaedic wounds. He also made a vital contribution to the management of the most severe orthopaedic wound on theWestern Front, the compound fracture of the femur caused by bullet or shell fragment, by introducing the Thomas Splint to deal with this problem. He was encouraged to do so by his friend and colleague Henry Gray (Figure 3) who was emerging as the leading authority in musculoskeletal surgery in CCSs serving the Western Front.

Gray (1870-1938) was born in Aberdeen, the son of a wholesale provision merchant. He studied medicine at the University of Aberdeen, graduating in 1895. He became a Fellow of the Royal College of Surgeons of Edinburgh, was appointed assistant surgeon to the Royal Infirmary of Aberdeen in 1899 and consultant surgeon in 1904, a position he held until the outbreak of the war in 1914 . He is credited with bringing aseptic surgery to Aberdeen and local anaesthesia to surgery in Great Britain. ${ }^{8}$ Gray, like Jones, was one of the founding members of Moynihan's Provincial Surgeons' Club. ' He spent three and a half years in France during the First World War, first as Consulting Surgeon to a group of base hospitals in Rouen, then Consulting Surgeon to the British Third Army.

At the outbreak of war, the Royal Army Medical Corps (RAMC) employed a modified Liston Splint to immobilise fractures of the femur. The Edinburgh surgeon Robert Liston ( 1794-1847) had been an important establishment figure in London in the nineteenth century. He left Edinburgh because he was very unpopular with his colleagues for abrasive and argumentative behaviour and became Professor of Surgery at University Hospital London in 1835. He was noted for his speed of surgery, amputating a leg in a few minutes, although on one occasion he allegedly inadvertently removed the patient's testicles at the same time. Liston developed a splint for immobilising fractures of the femur, which was a long pole extending from axilla to foot, strapped to the patient's trunk and limb. The RAMC employed a similar 'Rifle Splint' (Figure 4).

The Rifle Splint was not fit for purpose as it failed to immobilise the fracture. By the time patients were transported to CCSs, most were moribund from excessive blood loss and unfit to withstand radical excision of contaminated and devitalised tissue, which was necessary to save limbs and lives. Gray documented the mortality of compound fractures of the femur in 1914 and 1915 to be $70-80 \% .^{10}$

Gray encouraged Jones to use the Thomas Splint, which was similar to the one shown in Figure 5. Skin traction apparatus was attached from groin to ankle. Cords tied under tension round the bottom of the splint maintained longitudinal traction, overcoming muscle spasm in the thigh and maintaining good fracture alignment. Movement between bone ends at the fracture site was diminished and blood loss was reduced. The majority of patients reached CCSs haemo-dynamically stable and able to withstand major surgery.

By 1917, Gray was Consulting Surgeon to the British Third Army and responsible for administering surgical care to its soldiers when it attacked at the Battle of Arras on 9 April 1917. The battle lasted six weeks during which time 1,009 compound fractures of the femur were admitted to CCSs. ${ }^{10}$ Gray instructed all regimental medical officers in the application of the Thomas Splint and they, in turn, taught their stretcher bearers. Each Regimental Aid Post was equipped with approximately ten Thomas Splints to transport patients with compound fractures of the femur to nearby CCSs specialising in the management of such wounds. 
Before 1917, when the majority of femoral fractures were inadequately splinted, Gray quoted a mortality of $50 \%$ in CCSs; ${ }^{10}$ others died before reaching there. One proposed management regime was that all compound femoral fractures should be treated by amputation using 'a quick whiff of nitrous oxide and oxygen', since this least harmful anaesthetic regime might salvage a few shocked soldiers who otherwise would have died undergoing major limb sparing surgery. Fortunately, in Gray's series, using the Thomas Splint, only 5\% were unfit for limb salvage surgery. His mortality rate was $15.6 \%$, a reduction of more than $30 \% .^{10}$

Gray's amputation rate was only 17.2\%. Many of these patients had major nerve or blood vessel damage or were infected beyond any hope of salvage, making amputation the only feasible option. Gray observed that of those who died, many had lain in No Man's Land for many hours and were beyond surgical help..$^{10}$

\section{WOUND EXCISION TECHNIQUE FOR LIMB- SALVAGING SURGERY IN COMPOUND FEMORAL FRACTURES}

By October 1914, Gray realised the importance of removing all devitalised and contaminated tissues from wounds. In 1915, the technique of wound excision became firmly established. The anaerobic conditions predisposing to gas gangrene were thereby eliminated. Sometimes wounds looked innocuous and there was a temptation to transfer patients with such wounds to base hospitals for surgery. This was a mistake, because tissue contamination was always worse than first appearances sometimes suggested.

The field dressing and splint were removed under general anaesthesia in an operating theatre in the CCS. Entrance and exit wounds were extended widely. There was invariably a huge amount of dead muscle which was excised until only healthy bleeding muscle remained Bone ends were cleansed of filth, and loose fragments of bone with no soft tissue attachments were removed. All foreign bodies were removed. At the completion of the procedure only healthy, viable tissue remained. This systematic aggressive excision of all devitalised tissue was the fundamental principle of war surgery.

In favourable cases, operated on before infection was established, Gray advocated primary closure of the wound." If there was doubt about the completeness of the surgical excision, delayed primary closure was employed, taking a 'second look' two or three days after the wound excision and closing the wound if all was well. The second look was usually performed at a base hospital, the primary excision having been carried out at a CCS. Gray used hypertonic salt dressings packed into the wound after primary wound excision. The pack was removed at the time of delayed primary closure.
In cases where wounds were already infected on admission to CCSs, patients first underwent excision of the wound, before it was either packed with hypertonic salt dressings or irrigated with antiseptic agents such as flavine, iodoform, boric acid or Dakin's solution, which used sodium hypochlorite as its active ingredient. Antiseptics were sometimes helpful but were no substitute for surgical removal of dead, contaminated tissue. Granulation tissue gradually covered the wound surfaces, provided those surfaces had a blood supply. The wound could usually be closed secondarily after two to three weeks. In hopelessly infected cases, amputation was the best initial option.

An experienced surgeon was needed to make the right decision for each individual patient. Casualty clearing stations dealing with compound fractures of the femur were staffed by surgeons familiar with such wounds. Patients were transferred to special designated general or stationary hospitals at base where they remained for six weeks until the fracture was 'sticky' and at low risk of losing position during transfer back to Britain. During the Battle of the Somme in 1916, there were 3,173 compound fractures of the femur in designated general and stationary hospitals in France awaiting return to Britain. ${ }^{12}$ For practical purposes, stationary and general hospitals differed only in size, general being larger. By 1917, three newly built general hospitals each had 2,500 beds. ${ }^{12}$

When mobile warfare returned on 21 March 1918 with the German spring offensive, CCSs lost their semipermanent status and reverted to the use of large tents. Jones did not believe that it was possible to treat patients with femoral fractures in a tent since there was nowhere to suspend heavy weights and beams necessary to maintain the reduction of fractures. Some patients arrived in Britain with several inches of shortening requiring treatment either by traction alone or by oblique osteotomy at the healing fracture site followed by traction in order to restore length. ${ }^{13}$

\section{HENRY GRAY'S OTHER ACHIEVEMENTS}

Gray was regarded as perhaps the most capable military surgeon of his generation. He published work in the British Medical Journal on subjects including infected gunshot wounds, ${ }^{14}$ gunshot wounds of the head ${ }^{15}$ and gas gangrene. ${ }^{16}$ If a wound were thoroughly excised and all devitalised tissue removed, then the patient would not develop gas gangrene. If a patient had gangrene, he could only be saved by excision of all dead tissue. Gray removed a bullet from a soldier's heart under local anaesthetic, confirming that he, like all British surgeons of his era, was a general surgeon. ${ }^{17}$

Gray worked extensively on the treatment of penetrating wounds of the knee joint. ${ }^{18}$ Early in the war, such wounds usually resulted in loss of limb or life, as they had 
throughout the nineteenth century. According to Gray, 'at the record of a healed stiff joint, one felt almost inclined to cheer, while the story of movement following an operation sounded like a fairy tale. ${ }^{\prime 0}$

Early surgery followed by primary closure was of paramount importance to preserve joint function. If infection supervened, joint disintegration with complete loss of function invariably resulted. This was often associated with a breakdown of the patient's general resistance so that amputation was the only way to save the patient's life. Great experience was required to excise the wound and still be able to close the joint. Sometimes it proved impossible to close the skin completely, but if the synovial membrane could be approximated, effectively excluding the knee joint from the outside world, then a satisfactory outcome could be anticipated. 'Now what were fairy tales are commonplace, and great is the satisfaction to those who were out in the dark days of surgery, commented Gray in his 1919 work, The early treatment of war wounds..$^{10}$

\section{GRAY'S STRENGTHS AND WEAKNESSES}

Gray was highly regarded as a surgeon by his peers. John Lynn Thomas, Deputy Inspector of Military Orthopaedics, Western Command, acknowledged Gray's contribution to the management of septic wounds of the limbs. ${ }^{19}$ Andrew Dillan Carberry, who wrote The history of the New Zealand Medical Services in the Great War, said of Gray:

The Third Army - which the New Zealanders found to be no less highly organised than our own much admired Second Army - early in May re-opened its schools of instruction temporarily interrupted by the German invasion. Surgery especially that of the front line was a specialty of this Army, whose Consulting Surgeon, Colonel HMW Gray was noted since 1916 for his work in the treatment of compound gunshot fractures. His memoranda, issued by the Third Army in 1917 formed the basis of the front line surgical practice of this and other armies, and his well known book, The Early Treatment of War Wounds, ... epitomised the advancing knowledge of that period. ${ }^{20}$

Gray loved working with the young surgeons whom he supervised at CCSs and regarded it a great privilege to have been able to make constructive recommendations for the management of wounded soldiers which were 'the outcome of concentrated observation and thought by one who has had unusual opportunities, and of discussion with numerous brilliant young surgeons possessed of fresh active brains and equally dexterous hands'. ${ }^{10}$
Unfortunately, while Gray's work as a surgeon was admired by his peers, he often did not get on with them. Following the publication of Gray's book The early treatment of war wounds in 1919, based on a series of scientific papers written by Gray and published during the war, Sir Anthony Bowlby attempted to discredit the evidence for the high mortality of patients with a compound femoral fracture in the early years of the war, declaring it to have been significantly less than the quoted figure of $80 \%$. He said it was only $16 \%$ at CCSs in 1915.1

'Had his remarks gone unchallenged, then those who had not given serious consideration to the matter would receive a wrong impression of the appalling seriousness of this injury, especially in the early years of the war,,22 Gray responded in a strongly worded letter to the British Medical Journal, declaring Bowlby's figures had been based on notoriously inaccurate 1915 admission books at CCSs. At the three CCSs used by Bowlby, only I4I cases of compound fractures of the femur were recorded, with 23 deaths giving a mortality of $16 \%$.This was a far smaller number of cases than would have been expected to have occurred during that period. The accepted incidence of compound femoral fractures was one per 50-60 admissions. Bowlby should have had 500 more cases on which to base his mortality assessment. In cases of multiple wounds admitted to CCSs the fractured femur was often not even mentioned and some other component of the patient's injuries was documented in the record. Gray, in contrast, had based his assessment on a careful study of all cases when he arrived at a mortality figure of $80 \%$.

Gray felt that Bowlby had attempted to diminish appreciation of the excellent progress in the handling of such cases: 'Speaking generally, the enormous improvement in treatment and consequently results is one of the brightest records of the medical service. ${ }^{22}$

\section{AMERICAN CONTRIBUTION}

While Gray made progress in the management of musculoskeletal wounds in CCSs, Jones experienced staffing problems in Britain's orthopaedic centres, which had 20,000 beds in total. Junior medical officers working in orthopaedic centres were frequently sent to the Western Front. Help came from American orthopaedic surgeons when the USA entered the war in April 1917. American surgeons had been frequent visitors to Jones' clinics and operating sessions in Liverpool before the war and greatly admired his work. Intially 20 orthopaedic surgeons under Joel Goldthwaite came to Britain; paid by the US Military, they were put at Jones' disposal. Soon another 60 surgeons came across to work in orthopaedic centres around Britain. ${ }^{5}$ 
In May 1917, the American surgeon Robert Osgood visited those orthopaedic centres where American surgeons were employed. While in Britain, Osgood made an important contribution by stimulating confidence among British surgeons to establish the British Orthopaedic Association. ${ }^{5}$ The inaugural meeting was held in the Café Royal, London, on 28 November 1917 and the first scientific meeting was held on 2 February 1918.

\section{JONES AND GRAY AFTER THE WAR}

After the war, Jones hoped that orthopaedic surgery would flourish and that orthopaedic departments would be attached to hospitals, but it was not to be. Symbolic of the prevailing mood, and in no small measure due to professional jealousy and rivalry, Shepherd's Bush was restored to its original workhouse state. It would be many years before orthopaedic surgery finally re-emerged to be recognised as a specialty in its own right.

\section{REFERENCES}

I Westhorpe R. The introduction of a mobile resuscitation service - 1918. In: Fink BR, editor. The History of Anaesthesia Third International Symposium. Illinois; 1992. p.435-8

2 Whitehead IR. Doctors in the Great War. Barnsley: Leo Cooper; 1999. p.206-7

3 Macpherson WG. History of The Great War based on official documents. Medical Services General History Vol. III. London: HMSO; 1924.

4 Mitchell TJ, Smith GM. History of the Great War Medical services casualties and medical statistics. London: HMSO; 1931. p.40.

5 Watson F. The life of Sir Robert Jones. London: Hodder \& Stoughton; 1934.

6 Platt H. Moynihan: the education and training of the surgeon. Ann $R$ Coll Surg Engl 1962; 30:220-8.

7 Makins GH. Introductory. $\mathrm{Br}$ J Surg 1918; 6:I-II. doi:I0.1002/ bjs. 1800062102

8 Porter RM. Recent Aberdeen teachers: Sir Henry Gray, KBE, CB CMG, LLD, FRCS(Ed). Aberdeen Postgrad Med Bull I 97।; I I-3.

9 Smith FK. Sir Henry Gray, KBE, CB, CMG. Aberdeen University Review 1938-39; XXVI:47-8.

I0 Gray HM. The early treatment of war wounds. London: Henry Frowde and Hodder \& Stoughton; 1919.

II Gray HM. Treatment of gunshot wounds by excision and primary closure. Br Med J 1915; 2:317.

12 Macpherson WG. History of the Great War based on official documents. Medical Services General History Vol. II. London: MacMillan; 1923
Jones returned to Liverpool after the war and became the father figure of British orthopaedic surgery. He had established a hospital in Oswestry before the war with Agnes Hunt. In the fullness of time, the Robert Jones and Agnes Hunt Hospital would become recognised as a centre of orthopaedic excellence.

Gray returned to Aberdeen, but he never settled. He was awarded a knighthood and became an Honorary LLD University of Aberdeen, both for his services to war surgery. He emigrated to Canada to fill the position of Chief of Surgery at the Royal Victoria Hospital in Montreal, but didn't fit in. He fell from favour ${ }^{23}$ and disappeared into surgical obscurity.

Henry Gray's name is unknown in his home city of Aberdeen. It is as though his major contributions to war surgery had never been. Perhaps, in the 100th anniversary of the 'war to end wars' it is time to put this right.

13 Jones R. An Address on the orthopaedic outlook in military surgery. Br Med J 1918; I:4I-5.

14 Gray HM.Treatment of 'gunshot wounds' of the knee-joint. Br Med J I9I5; 2:4I-3.

15 Gray HM. Observations on gunshot wounds of the head. Br Med J 1916; I:261-5.

16 Gray HM. An essential principle in the treatment of gas gangrene. Br Med J 1918; I:369.

17 Birkbeck LH, Lorimer GN, Gray HM. Removal of a bullet from the right ventricle of the heart under local anaesthesia. $\mathrm{Br}$ Med J 1915; 2:56I-2.

18 Gray HM. Early treatment of gunshot wounds of the knee-joint. $\mathrm{Br}$ Med J 19|7; 2:278-80.

19 Lynn Thomas J.A simple modification of the guillotine or flapless method of amputation. Br Med J 1916; 2:48I-2.

20 Carberry AD. The New Zealand Medical Services in the Great War. Auckland:Whitcombe and Tombs; 1924

21 Bowlby A.The mortality of cases of fractured femur. Br Med J 1919; I:II2.

22 Gray HM.The mortality of cases of fractured femur. Br Med J 1919; I:I42.

23 Adam A, Hutchison JD, Scotland TR. The strange case of Sir Henry Gray. Scot Med J 2010; 55:34-7. 